\title{
Edukasi teknologi hidroponik untuk pemberdayaan lahan pekarangan
}

\author{
Ismail $^{1}$, Agus Syam ${ }^{2}$ \\ ${ }^{1}$ Fakultas MIPA, Universitas Negeri Makassar \\ ${ }^{2}$ Fakultas Ekonomi, Universitas Negeri Makassar
}

\begin{abstract}
The acceleration of diversification of food consumption based on local resources has become a government policy. One form of the implementation of the policy is the optimization of the use of the yard. To optimize the function of the yard as a source of vegetable food, training in hydroponic technology education activities has been conducted with community partners in the village of Tunikamaseang, Maros Regency. The Community Partnership Program is carried out with the aim of increasing: 1) hydroponic system vegetable farming techniques and skills, 2) increasing family food security. The method used is the reflection, demonstration and practice of hydroponic system cultivation, with the Participatory Rural Appraisal approach. The result of devotion achieved is an increase in partner's knowledge and skills in the cultivation of the hydroponic system. The output of this activity is the vegetable cultivation model of the hydroponic system.
\end{abstract}

Keywords: education, hydroponics, yard

\section{PENDAHULUAN}

Peraturan Presiden Nomor 22 Tahun 2009 tentang Percepatan Penganekaragaman Konsumsi Pangan Berbasis Sumber Daya Lokal dikeluarkan untuk mendorong percepatan penganekaragaman konsumsi pangan melalui kerjasama sinergis antara pemerintah, pemerintah daerah dan masyarakat. Salah satu wujud implementasi kebijakan tersebut adalah optimalisasi pemanfaatan pekarangan rumah.

Bagi keluarga yang kurang mampu, pemanfaatan pekarangan untuk budidaya sayuran sangatlah strategis. Pekarangan merupakan sebidang lahan yang berada di sekitar rumah (Arifin et al., 1997). Selain pekarangan difungsikan untuk pemenuhan bahan pangan, pekarangan juga untuk konservasi keanekaragaman hayati (Arifin et al., 2007) dan mendukung agroekologi dan pertanian yang keberlanjutan (Marshall \& Moonen, 2002). Oleh karena itu, apabila dikelola secara optimal produktivitas lahan pekarangan dapat ditingkatkan guna peningkatan ketahanan pangan keluarga.

Optimalisasi lahan pekarangan dapat dilakukan dengan memanfaatkan semua zonasi pekarangan untuk budidaya tanaman beragam tanaman (Azra et al., 2014). Untuk optimalisasi pekarangan, perlu adanya penganekaragaman pangan agar banyak ragam pangan yang bisa dikonsumsi dalam setiap harinya. Pekarangan diharapkan mampu memenuhi sebagian kebutuhan sayuran pada tingkat rumah tangga sehingga memungkinkan peningkatan ketahanan pangan keluarga. Harapan ini menjadi lebih berarti pada kelompok masyarakat tertentu, seperti keluarga kurang mampu.

Pemberdayaan pekarangan dengan memanfaatkannya sebagai kebun sayuran telah terbukti berkontribusi dalam peningkatan ketahanan pangan, dan gizi keluarga (Carney et.al., 2012), meningkatkan pendapatan keluarga dan pengentasan kemiskinan (Talukder et al., 2010). Instrumen penting dalam pemberdayaan adalah memberikan edukasi yang akan mengubah kondisi kehidupan dengan pengetahuan dan keterampilan.

Desa Tunikamaseang merupakan salah satu desa di Kecamatan Bonto Kabupaten Maros Sulawesi Selatan. Desa ini memiliki luas $6,24 \mathrm{~km}^{2}$ berada pada ketinggian 0-45 mdl. Desa Tunikamaseang tergolong desa swasembada, terbagi ke dalam $23 \mathrm{RT}$ terdiri atas $677 \mathrm{KK}$ dengan jumlah penduduk 3.502 jiwa. Sebagai desa yang berbatasan langusng dengan laut, desa ini memiliki areal tambak seluas 247,45 Ha dan areal persawah- 
an seluas 141,34 Ha seluruhnya merupakan sawah tadah hujan. Gambar 1 memperlihatkan pusat pemerintahan Desa Tunikamaseang yang dikelilingi oleh areal tambak, tempat dimana kegiatan dilaksanakan.

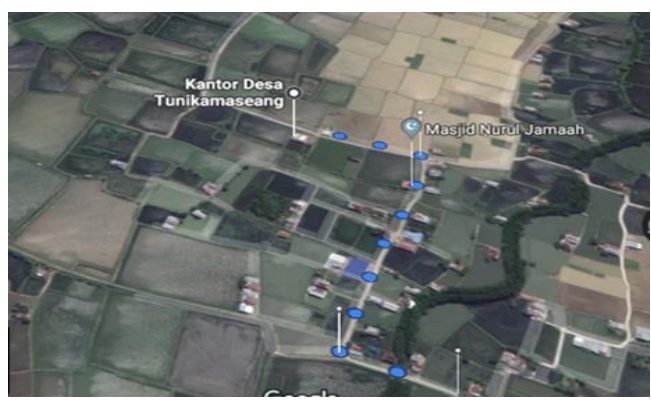

Gambar 1. Gambaran lokasi kegiatan PKM Desa Tunikamaseang Kabupaten Maros

Sebagai wilayah pesisir pantai, budidaya sayuran dalam wilayah desa Tunikamaseang sangat terbatas. Untuk memenuhi kebutuhan sayuran, masyarakat harus membeli di pasar yang digelar hanya pada hari tertentu. Optimalisasi fungsi pekarangan dengan budidaya sayuran dibatasi oleh faktor tanah yang kurang mendukung. Sebagai daerah pesisir pantai, jenis tanah di desa ini diketahui miskin hara dan senyawa organik sehingga kurang sesuai untuk budidaya sayuran. Dengan demikian, untuk mengoptimalkan fungsi pekarangan, perlu adanya inovasi teknologi budidaya sayuran, yaitu teknologi hidroponik.

Teknologi budidaya sistem hidroponik dapat mengatasi kendala terbatasnya sumber nutrisi tumbuhan yang tersedia di dalam tanah. Permasalahannya adalah keluarga khususnya keluarga kurang mampu terkendala oleh kurangnya pengetahuan dan keterampilan dalam budidaya sayuran sistem hidroponik. Untuk mengatasi keterbatasan tersebut, masyarakat membutuhkan pelatihan dan pendampingan budidaya sayuran sistem hidroponik. Pelatihan teknologi budidaya sistem hidroponik ini dilaksanakan bersama mitra masyarakat Desa Tunikamaseang Kabupaten Maros dalam Program Kemitraan Masyarakat (PKM).

\section{METODE PELAKSANAAN}

Kegiatan PKM ini dilaksanakan melalui serangkaian kegiatan dengan metode alih teknologi dan pembuatan contoh serta pendampingan dengan pendekatan Participatory Learning and Action (PLA). Pendekatan ini bertujuan untuk memastikan keterlibatan secara aktif secara individu maupun organisasi, dalam seluruh kegiatan dan pembelajaran mulai dari proses perencanaan, pelaksanaan, pemantauan dan pemanfaatan hasil. Pendekatan PLA dilakukan dengan alasan antara lain para mitra dapat secara langsung berdiskusi dan melihat contoh hasil kegiatan. Secara teknis, pemberdayaan masyarakat dilakukan dalam bentuk pendampingan untuk memberikan rangsangan dan respon terhadap perubahan. Kegiatan dilaksanakan dengan metode ceramah dan diskusi, demonstrasi, dan praktik kerja.

\section{A. Ceramah Budidaya Sistem Hidroponik}

Ceramah budidaya sistem hidroponik dilakukan sebagai pengenalan seputar teknologi hidroponik. Materi pelatihan yang diberikan adalah: 1) pengantar dasar hidroponik; 2) pengenalan alat dan bahan hidroponik; 3) teknik-teknik budidaya sistem hidroponik; 4) media tanam; 5) cara budidaya sistem hidroponik; 6) pembibitan dan penanaman, dan 7) pemeliharaan tanaman. Ceramah diselingi dengan tanya jawab. Gambar 2 memperlihatkan kegiatan pelatihan budidaya sayuran dengan teknologi hidroponik.

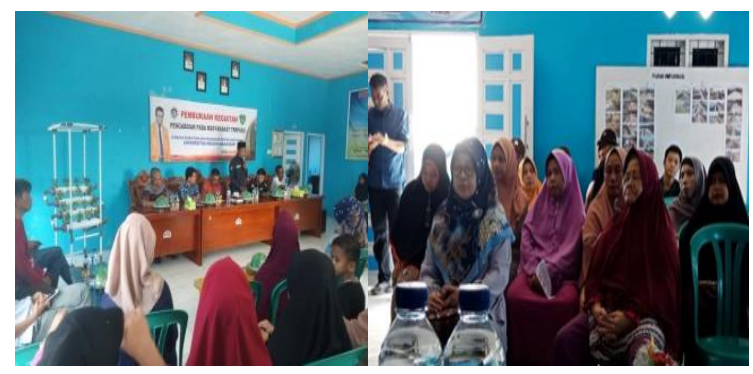

Gambar 2. Gambaran peserta pelatihan budidaya tanaman sistem hidroponik 


\section{B. Demonstrasi dan Praktik Budidaya}

Kegiatan demontrasi bertujuan untuk menunjukkan dan memperkenalkan alat dan bahan, cara kerja, pembibitan dan penanaman. Cara membuat instalasi dan pembuatan larutan induk dan nutrien hidroponik. Sementara itu, Praktek kerja dilakukan secara berkelompok. Setiap kelompok terdiri atas 3-4 orang. Materi kerja kelompok meliputi: Cara membuat media tumbuh, pembuatan larutan induk dan nutrien AB Mix, cara penanaman, dan perawatan tanaman. Pembuatan instalasi hidroponik berbahan pipa PVC dan gabus styrofoam.

\section{Pembuatan Nutrisi Hidroponik}

Dimulai dengan pembuatan larutan induk dan pengencerannya, komposisi dan perbandingan, pengukuran derajat keasaman $(\mathrm{pH})$ dan konsentrasi larutan (ppm), seperti terlihat dalam Gambar 3.
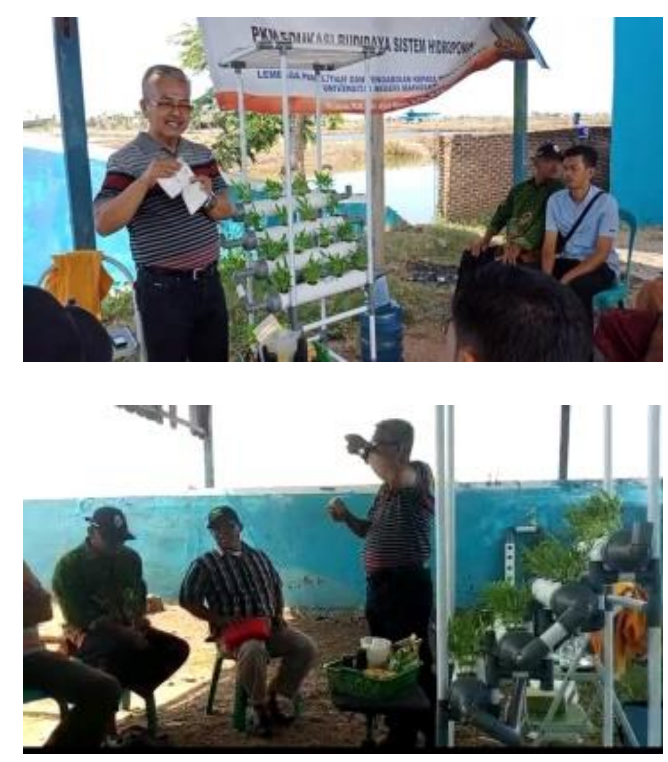

Gambar 3. Kegiatan demonstrasi budidaya sistem hidroponik

\section{HASIL DAN PEMBAHASAN}

Hasil dan luaran yang diperoleh pada kegiatan pengabdian ini diuraikan sebagai berikut.

\section{A. Pengetahuan Budidaya Sistem Hidroponik}

Hasil kegiatan pelatihan tentang beberapa aspek budidaya sistem hidroponik meningkat. Jika sebelum pelatihan pengetahuan awal peserta terbatas pada pengertian budidaya tanaman hidroponik, maka setelah pelatihan dilaksanakan peserta memiliki pengetahuan budidaya hidroponik dalam beberapa aspek, termasuk pengetahuan alat dan bahan dengan masing-masing fungsinya, serta nutrisi hidroponik. Pertanyaan teknis yang diajukan di sela-sela berlangsungnya ceramah dan pelatihan dijawab dengan benar oleh peserta pelatihan. Beberapa materi pertanyaan yang diajukan, seperti: nutrien dan media tanam, serta alat-alat dan fungsinya serta bahan-bahan yang digunakan seperti: net pot, rockwoll, kain planel, instalasi hidroponik, alat pelubang, dan larutan stok (pekatan).

\section{B. Keterampilan Budidaya Sistem Hidroponik}

Peserta pelatihan telah memiliki keterampilan terkait dengan budidaya sayuran sistem hidroponik, mulai dari teknik pembuatan dan merangkai instalasi hidroponik, pembuatan media tanam, dan sistem penanaman dan perawatan tanaman.

\section{Luaran Kegiatan}

Dari pelaksanaan kegiatan PKM ini diperoleh luaran berupa model budidaya sayuran sistem hidroponik, baik dengan penggunaan instalasi hidroponik maupun dengan budidaya sayuran dengan hidroponik sederhana (Gambar 4).

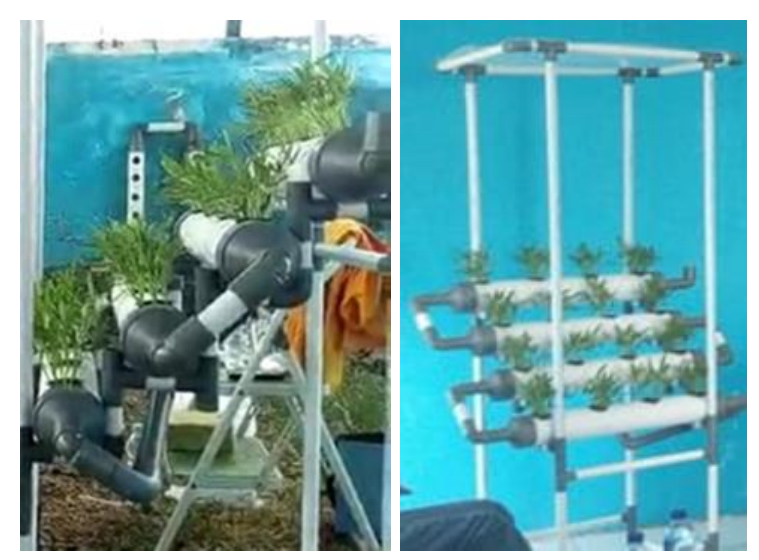

Gambar 4. Produk luaran model budidaya sayuran hidroponik

Dengan pengetahuan dan keterampilan budidaya tanaman sistem hidroponik yang telah dimiliki diharapkan akan memberikan dampak ekonomi bagi keluarga. Peningkatan relatif penghasilan keluarga dapat meningkat. Peningkatan relatif penghasilan yang dimaksud adalah pengurangan biaya kebutuhan sayuran. Sebagai 
gambaran, nilai jual hasil budidaya sayuran kangkung secara hidroponik (Ismail, 2018) diketahui bahwa hasil bersih panen kangkung dan bayam dengan 35 lubang tanam sebesar $\mathrm{Rp}$ 28.000,- untuk setiap periode tanam 21 hari.

Selain difungsikan untuk pemenuhan bahan pangan, pekarangan juga untuk konservasi keanekaragaman hayati pertanian (Arifin et al., 2007) dapat juga mendukung agroekologi dan pertanian yang keberlanjutan (Marshall \& Moonen, 2002). Oleh karena itu, apabila dikelola secara optimal produktivitas lahan pekarangan dapat ditingkatkan guna peningkatan ketahanan pangan keluarga.

Terlepas dari hasil akhir program khususnya dalam pengembangan sayuran organik bagi keluarga, penting untuk digarisbawahi bahwa program ini pada dasarnya bersifat inisiasi bagi keluarga khususnya kurang mampu, memberikan pilihan hidup untuk bisa mengentaskan keluarganya dari kondisi keterbatasan ekonomi, meningkatkan daya lenting bagi peningkatan kesejahteraan keluarga.

Sebagai kegiatan inisiasi tentu saja tingkat keberhasilannya sangat terkait dengan beberapa pihak, diantaranya pemerintah setempat. Kesediaan keluarga untuk terlibat dalam program ini harusnya dimaknai sebagai keinginan kuat untuk keluar dari kondisi ketidakberdayaan pangan. Untuk itu dibutuhkan pelibatan aktif pemerintah dan tokoh masyarakat setempat dalam hubungan kerja kolektif-kolegial. Ketiadaan pelibatan diri pemerintah dan tokoh masyarakat, maka berbagai program dapat berakhir gagal.

Dengan demikian, keberlanjutan dan keberhasilan program ini diperlukan tindakan pembinaan berkelanjutan. Untuk mengadopsi suatu teknologi yang baru dibidang tani sangat diperlukan suatu program lanjutan dan berkesinambungan dari waktu ke waktu secara optimal.

\section{KESIMPULAN}

Dari hasil kegiatan PKM ini dapat disimpulkan bahwa:

1. Pengetahuan peserta tentang budidaya sayuran sistem hidroponik meningkat setelah mengikuti kegiatan pengabdian kepada masyarakat ini.

2. Keterampilan peserta dalam budidaya tanaman hidroponik meningkat. Peningkatan pengetahuan ini dipantau tidak hanya pada saat mengikuti pelatihan, tetapi pelaksana juga melakukan pemantauan setelah kegiatan selesai.

\section{UCAPAN TERIMA KASIH}

Ucapan terima kasih disampaikan kepada Direktorat Jendral Pendidikan Tinggi yang telah memberikan hibah. Selanjutnya ucapan terima kasih disampaikan pula kepada Rektor UNM atas arahan dan pembinaannya selama proses kegiatan Pengabdian Masyarakat berlangsung. Demikian pula ucapan terima kasih disampaikan kepada Ketua Lembaga Penelitian dan Pengabdian Kepada Masyarakat UNM dan Pemerintah Kabupaten Maros Provinsi Sulawesi Selatan, yang telah memberi fasilitas, melakukan monitoring, dan mengevaluasi kegiatan PKM hingga selesai.

\section{DAFTAR PUSTAKA}

Arifin HS, Sakamoto K, Chiba K. 1997. Effects of the Fragmentation and the Change of the Social and Economical Aspects on the Vegetation Structure in the Rural Home Gardens of West Java, Indonesia. Japan Institue of Landscape Architecture J., Tokyo. Vol.60 (5): 489-494.

Arifin HS, Munandar A, Mugnisjah WQ, Budiarti T, Arifin NHS, Pramukanto P. 2007. Homestead Plot Survey on Java. Research Report. Department of Landscape Architecture \& Rural Development Institute (RDI) SeattleUSA.

Azra, A. L. Z., H. S. Arifin, M. Astawan \& N.HS Arifin 2014. Analisis Karakteristik Pekarangan dalam Mendukung Penganekaragaman Pangan Keluarga di Kabupaten Bogor. Jurnal Lanskap IndonesiaVol 6 No. 2.2014 . 
Carney, P.A., J.L. Hamada, R. Rdesinsky, L. Sprager, K.R. Nichols, B.Y. Liu, J.Pelayo, M.A. Sanches, \& J.Shannon. 2012. Impact of a Community Gardening Project on Vegetable Intake, Food Security and Family Relationships: A Community-based Participatory Research Study. J Community Health. 2012 Aug; 37(4): 874-881.

Ismail, R. Ngitung, dan Nurhikmah. 2018. Optimalisasi fungsi pekarangan untuk peningkatan ketahanan pangan keluarga kurang mampu. Prosiding Seminar Nasional Lembaga Pengabdian Kepada Masyarakat Universitas Negeri Makassar ISBN: 978-602-555-459-9.
Marshall, E.J.P., Moonen, A.C., 2002. Field margins in northern Europe: their functions and interactions with agriculture. Agric. Ecosyst. Environ. 89, 5-21.

Talukder,A., N.J. Haselow, A.K. Osei, E. Villate, D. Reario, H. Kroeun, L. SokHoing, A. Uddin, S. Dhunge and V. Quinn. 2010. Homestead food production model contributes to improved household food security and nutrition status of young children and women in poor populations lessons learned from scaling-up programs in Asia (Bangladesh, Cambodia, Nepal and Philippines). Field Actions Science Reports The journal of field actions. 